\title{
Determinants of PMTCT Examination Using the Health Belief Model Approach in Makassar City in 2019
}

\author{
Bety Anisa Wulandari ${ }^{*}$, Arifin Seweng ${ }^{1}$, Muhammad Arif Tiro² \\ 1Department of Biostatistics, Faculty of Public Health, Hasanuddin University, Indonesia \\ 2Department of Statistics, Mathematics and Natural Sciences Faculty, Makassar State University, Indonesia \\ *Corresponding Author \\ Bety Anisa Wulandari \\ Article History \\ Received: 04.12.2019 \\ Accepted: 14.12 .2019 \\ Published: 22.12.2019
}

\begin{abstract}
Prevention of HIV transmission from mother to child or Prevention of Mother to Child Transmission (PMTCT) is part of efforts to control HIV-AIDS and Sexually Transmitted Infections (STIs). In Indonesia, there were 1,805,993 pregnant women tested for HIV and there were $5,074(0.28 \%)$ pregnant women who were HIV positive. The purpose of this study was to analyze the determinants of PMTCT examination with the Health Believe Model approach in Makassar City in 2019. This study was an observational analytic study with a cross-sectional design. The sample in this study was 260 pregnant women in the working area of the Sudiang Raya Health Center and Antang Perumnas Makassar City. Data were analyzed using chi square and multiple logistic regression. The results showed that the cues acted influentially on PMTCT examination with $p$-value $=0.014(p<0.05)$ with OR = 6.013 , and there were some insignificant variables such as threat perception variable with $p$-value $=1,000(p>0,05)$, the perception of the benefits of $p$-value $=0.143(p>0.05)$ and the perception of resistance $p$-value $=0.340(p>0.05)$. It was concluded that the cues acted influentially on the PMTCT examination and to the perception of threats, perceived benefits, and perceived barrier did not affect the PMTCT examination in Makassar City. It is expected that health workers explain in advance about the actions that will be taken (PMTCT examination), and provide information about the importance of efforts to prevent HIV transmission from mother to baby.
\end{abstract}

Keywords: PMTCT examination, Pregnant Women, Health Belief Model.

\section{INTRODUCTION}

HIV is an infectious disease caused by infection with the Human Immunodeficiency Virus which attacks the immune system [1]. AIDS is a disease caused by the retrovirus Human Immunodeficiency Virus (HIV) and is characterized by an immunosuppressed condition that triggers opportunistic infections, secondary neoplasms, and neurological manifestations [2].

Globally, HIV incidence has decreased from 0.40 per 1,000 uninfected populations in 2005 to 0.26 per 1000 uninfected populations in 2016. The African region remains the most affected by HIV, with an incidence rate of 1.24 per 1,000 uninfected populations in 2016. In 2016, an estimated 1 million people died due to HIV-related illnesses, 120,000 of whom were children under the age of 15 . The global increase in antiretroviral therapy (ART) has been a major driver of a $48 \%$ reduction in HIV-related deaths from a peak of 1.9 million in 2005. In mid-2017, around 20.9 million people received ART. However, antiretroviral therapy only reached $53 \%$ of people living with HIV at the end of 2016 and accelerated rapid response is needed to increase the scope of care, along with other interventions throughout the service chain, including prevention, diagnosis and chronic care [3].

According to data on the health profile of South Sulawesi province in 2018 out of 24 cities/regencies in South Sulawesi province, Makassar is the highest case of HIV / AIDS, with 772 HIV sufferers and 381 AIDS sufferers. Next is Bone with 77 HIV sufferers and 38 AIDS sufferers and Palopo with 71 HIV sufferers and 54 AIDS sufferers [4].

Factors related to the participation of pregnant women on PMTCT can be seen by using the Health Belief Model (HBM) approach. This HBM focuses on one's subjective perception, among others: one's perception of the risk of (perceived susceptibility), in this case, HIV / AIDS, one's perception of the seriousness of a disease both medical and social, such as death, exclusion from friends and family (Perceived severity), positive perceptions of preventive behavior (perceived benefit), negative perceptions of preventive

Copyright @ 2019: This is an open-access article distributed under the terms of the Creative Commons Attribution license which permits unrestricted use, distribution, and reproduction in any medium for non commercial use (NonCommercial, or CC-BY-NC) provided the original author and source are credited. 
behavior (perceived barriers), and Cues to Action wherein the construct it is explained that a behavior is influenced by something that becomes a signal for someone to take any action or behavior. Based on the description above, it can be seen that there are still high cases of HIV / AIDS and lack of PMTCT coverage, so a study was conducted to determine the determinants of PMTCT examination with the health belief model approach in Makassar City in 2019.

\section{Methodology \\ Research Design}

This type of research is an observational analytic study with the research design used is cross-sectional study. This research was conducted in the Sudiang Raya Health Center and Antang Perumnas Makassar City in September 2019.

\section{Population and Sample}

The population in this study were all pregnant women who did ANC in January-July 2019 in the working area of the Sudiang Raya Health Center as many as 605 pregnant women and Puskesmas Antang Perumnas as many as 413 pregnant women. The samples in the study were 260 respondents divided by 155 respondents in the Sudiang Raya Community Health Center and 105 in the Antang Public Health Center.

\section{Data Collection}

Data collection was carried out by distributing questionnaires that were prepared following the objectives of the study given to respondents selected as research samples at the Sudiang Raya Health Center and the Antang Perumnas Health Center.

\section{Data Analysis}

Research data analysis techniques used univariate analysis, bivariate analysis with Chi-Square test and multivariate analysis with multiple logistic regression in the SPSS For Windows Program.

\section{Results}

Table-1: Distribution of Pregnant Women Conducting PMTCT Checks Based on Mother Characteristics in Makassar City in 2019

\begin{tabular}{|l|l|l|l|}
\hline No & Characteristics & N & $\%$ \\
\hline 1. & Respondent's Age & & \\
& <20-35 Years Old & 222 & 85,3 \\
& $>35$ Years Old & 38 & 14,7 \\
\hline 2. & Respondent's Education & & \\
& Did Not School & 1 & 0,4 \\
& Elementary School & 12 & 4,6 \\
& Junior School & 32 & 12,3 \\
& High School & 130 & 50,0 \\
& Higher Education & 85 & 32,7 \\
\hline
\end{tabular}

Table-1 shows the characteristics of respondents consisting of age and education. Most respondents in the age group <2035 years old were $222(85.3 \%)$, while 38 respondents $(14.7 \%)$ were in the age group $>35$ years. For education variables, most respondents were high school education as many as 130 respondents $(50.0 \%)$, while the fewest respondents who were not in school were 1 respondent $(0.4 \%)$.

Table-2: Distribution of Pregnant Women Conducting PMTCT Checks Based on Perception in Makassar City in 2019

\begin{tabular}{|l|l|l|}
\hline Perception & $\mathbf{n}$ & $\%$ \\
\hline PMTCT Examination & & \\
Not PMTCT & 13 & 5,0 \\
PMTCT & 247 & 95,0 \\
\hline Perceived Threat & & \\
Less & & \\
Enough & 15 & 5,8 \\
\hline Perceived Benefit & 245 & 94,2 \\
Less & 3 & 1,2 \\
Enough & 257 & 98,8 \\
\hline $\begin{array}{l}\text { Perceived Barrier } \\
\text { Less }\end{array}$ & & \\
Enough & 8 & 3,1 \\
\hline $\begin{array}{l}\text { Cues to Action } \\
\text { Less }\end{array}$ & 252 & 96,9 \\
Enough & 21 & 8,1 \\
\hline
\end{tabular}


Table-2 shows the distribution of respondents based on research variables. Distribution of respondents based on PMTCT status, most respondents who were PMTCT were 247 (95.0\%) while respondents who were not PMTCT were 13 (5.0\%). Distribution of respondents based on the perception of threats mostly on the perception of threats is enough that as many as 245 respondents $(94.2 \%)$ while respondents who perceived the threat less as many as 15 respondents $(5.8 \%)$. Distribution of respondents based on the perception of benefits is mostly on the perception of benefits is enough that as many as 257 respondents $(98.8 \%)$ while respondents who perceived the benefits less as many as 3 respondents (1.2\%). Distribution of respondents based on the perception of barrier, most of the perception of barrier is enough that is as many as 252 respondents (96.9\%) while respondents who perceive barrier as much as 8 respondents (3.1\%). Distribution of respondents based on the act cues most of the respondents whose cues acted sufficiently were 239 respondents (91.9\%) while respondents with cues acted less as many as 21 respondents $(8.1 \%)$.

Table-3: Factors Affecting Pregnant Women Conducting Prevention of Mother to Child Transmission (PMTCT) Examinations in Makassar City in 2019

\begin{tabular}{|c|c|c|c|c|c|c|c|}
\hline \multirow[t]{3}{*}{ Variable } & \multicolumn{6}{|c|}{ PMTCT } & \multirow[t]{3}{*}{ Nilai $P$} \\
\hline & \multicolumn{2}{|c|}{ Not PMTCT } & \multicolumn{2}{|c|}{ PMTCT } & \multicolumn{2}{|c|}{ Total } & \\
\hline & $n$ & $\%$ & $\mathrm{n}$ & $\%$ & $\mathrm{n}$ & $\%$ & \\
\hline \multicolumn{8}{|l|}{ Threat } \\
\hline Less & 0 & 0,0 & 15 & 100 & 15 & 100,0 & \multirow[t]{3}{*}{1,000} \\
\hline Enough & 13 & 5,3 & 232 & 94,7 & 245 & 100,0 & \\
\hline Total & 13 & 5,0 & 247 & 95,0 & 260 & 100,0 & \\
\hline \multicolumn{8}{|l|}{ Benefit } \\
\hline Less & 1 & 33,3 & 2 & 66,7 & 3 & 100,0 & \multirow[t]{3}{*}{0,143} \\
\hline Enough & 12 & 4,7 & 245 & 95,3 & 257 & 100,0 & \\
\hline Total & 13 & 5,0 & 247 & 95,5 & 260 & 100,0 & \\
\hline \multicolumn{8}{|l|}{ Barrier } \\
\hline Less & 1 & 12,5 & 7 & 87,5 & 8 & 100,0 & \multirow[t]{3}{*}{0,340} \\
\hline Enough & 12 & 4,8 & 240 & 95,2 & 252 & 100,0 & \\
\hline Total & 13 & 5,0 & 247 & 95,0 & 260 & 100,0 & \\
\hline \multicolumn{8}{|c|}{ Cues to Action } \\
\hline Less & 4 & 19,0 & 17 & 81,0 & 21 & 100,0 & \multirow[t]{3}{*}{0,014} \\
\hline Enough & 9 & 3,8 & 230 & 96,2 & 239 & 100,0 & \\
\hline Total & 13 & 5,0 & 247 & 95,0 & 260 & 100,0 & \\
\hline
\end{tabular}

Table-3 shows the distribution of respondents based on research variables on the PMTCT examination. Respondents who did not have PMTCT were more likely to experience threat perception, namely 13 respondents $(5.3 \%)$ compared to respondents whose perception of threats was less with a $p$ value> 0.05 . Respondents who did not PMTCT were more likely to perceive sufficient benefits, namely 12 respondents (4.7\%) compared to respondents with less perceived benefits, namely 1 respondent (33.3\%) with a $p$ value $>0.05$. Respondents who did not have PMTCT were more likely to have experienced perceptions of barrier, namely as many as 12 respondents (4.8\%) compared to respondents whose perceptions of barrier were less than 1 respondent $(4.8)$ with a value of $p>$ 0.0 . Respondents who did not PMTCT were more likely to have acted enough cues as many as 9 respondents (3.8\%) compared to respondents with cues acting less namely as many as 4 respondents $(19.0 \%)$ with $p$ values $<0.05$.

Table-4: Multivariate Test Results Factors affecting pregnant women undergoing PMTCT examinations in Makassar City in 2019

\begin{tabular}{|l|l|l|l|l|l|l|l|}
\hline Variable & B & Wald & Df & P Value & OR & \multicolumn{2}{|c|}{ 95\% C.I.for Exp(B) } \\
\cline { 6 - 8 } & & & & & & Lower & Upper \\
\hline Cues to Action & 1,794 & 7,585 & 1 & 0,006 & 6,013 & 1,677 & 21,555 \\
\hline
\end{tabular}

Table-4 shows the conclusions of multivariate analysis with multiple logistic regression. of the 4 independent variables entered into the test simultaneously only gestures that have consistent significance. So it can be concluded that the gesture with an OR value of $6,013>1$ is a risk factor with a lower-upper value $=1677-21,555$, which means pregnant women who do not act with a cue have less than 6013 times greater chance of not doing PMTCT examination compared with pregnant women with the gesture is lacking.

\section{Discussion}

This study shows that the cues act influential on the examination of PMTCT in Makassar City. Cues to action in this research are derived from mass media information, advice from people around, personal or family experiences, articles or so forth. For gestures, it is felt more enough by pregnant women so that according to this study, the better the cues to act, the better the impact on PMTCT examination in Makassar and vice versa. This study is in line with Legiati et al., [5] showing that a statistical test with a 
significance level of $5 \%$ is obtained $p$-value 0,000 , which means that statistically there is a relationship between the cues of action with the behavior of HIV testing in pregnant women.

This study also shows that the perception of threats, perceived benefits and perceived constraints do not affect the PMTCT examination in Makassar City. For the threat perception variable, respondents have understood that the more threatened someone feels to suffer from an illness the more likely they are to adopt healthy behaviors. So that the perception of threats is more on the perception of threats enough, this is following the number of respondents who have already conducted PMTCT checks as a preventive measure. This study is in line with the Workagegn et al., [6] threat perception does not show a valid statistical relationship with the use of HIV testing of pregnant women in ANC services.

For the variable of perceived usefulness, perceived benefits perceived by the respondents in this case are very good for pregnant women, this is because most respondents are well aware that the benefits of PMTCT examination itself. This study is in line with Wenny et al., [7] that the perception of benefits was statistically not related to HIV testing in pregnant women. This study is not in line with the workagegn et al., [6] perception of the benefits of showing a statistically significant relationship with the use of HIV testing of pregnant women in ANC services.

For the obstacle perception variable, the perception of the obstacle felt by the respondent is within sufficient criteria or the respondent already knows the obstacle perceived by the respondent the higher the respondent's awareness of the PMTCT examination. This study is in line with the study of Wenny et al., [7] that the perception of barrier is statistically not related to HIV testing in pregnant women. This study is also in line with Arifin \& Abadi's research [8] where there is no statistically significant relationship between perceived barriers to the utilization of high risk group VCT in South Sulawesi.

\section{CONCLUSION}

Based on the results of research and discussion, it can be concluded that the cues act influential on PMTCT examination in pregnant women and the threat perception variables, perceived benefits and perceived obstacles do not affect the PMTCT examination in pregnant women. It is expected that health workers explain in advance about the actions that will be taken (PMTCT examination), and provide information about the importance of efforts to prevent HIV transmission from mother to baby.

\section{REFERENCES}

1. Ministry of Health. (2018). Pedoman Manajemen Program Pencegahan Penularan HIV dan Sifilis Dari Ibu Ke Anak. Jakarta. Ministry of Health of the Republic of Indonesia. Available form: https://siha.depkes.go.id/portal/ppia

2. Kumar, V., Abbas, A. K., Fausto, N., \& Aster, J. C. (2014). Robbins and Cotran pathologic basis of disease, professional edition e-book. Elsevier health sciences.

3. World Health Organization. (2018). World Health Statistics 2018. World Health Organization.

4. South Sulawesi Health Service. (2018). Profil Dinas Kesehatan Sulawesi Selatan. South Sulawesi, Indonesia.

5. Legiati, T., Shaluhiyah, Z., \& Suryoputro, A. (2012). Perilaku ibu hamil untuk tes HIV di kelurahan Bandarharjo dan Tanjung Mas kota Semarang. Jurnal Promosi Kesehatan Indonesia, 7(1):74-85.

6. Workagegn, F., Kiros, G., \& Abebe, L. (2015). Predictors of HIV-test utilization in PMTCT among antenatal care attendees in government health centers: institution-based cross-sectional study using health belief model in Addis Ababa, Ethiopia, 2013. HIVIAIDS (Auckland, NZ), 7:215.

7. Wenny, D. M., Subronto, Y. W., \& Hakimi, M. (2016). Faktor yang memengaruhi partisipasi ibu hamil melakukan skrining HIV di puskesmas Yogyakarta. Berita Kedokteran Masyarakat, 32(11):435-442.

8. Arifin, A., \& Abadi, M. Y. (2014). The analysis of factors affecting the use of VCT service for high-risk group infected with HIVIAIDS in Makassar. Online Repository, Hasanuddin University. 